\title{
A Comprehensive Study on Organized Retailing with Reference to Customer Preferences and Customer Loyalty in Indian Context
}

\author{
Pritam Chattopadhyay \\ Research Scholar, Amity University, Noida, Uttar Pradesh, India
}

\begin{abstract}
How to cite this paper: Pritam Chattopadhyay "A Comprehensive Study on Organized Retailing with Reference to Customer Preferences and Customer Loyalty in Indian Context" Published in International Journal of Trend in Scientific Research and Development (ijtsrd), ISSN: 24566470, Volume-3 | Issue-3, April 2019, pp.410-414, URL: http://www.ijtsrd.co $\mathrm{m} /$ papers/ijtsrd228 07.pdf

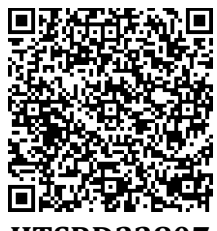

IITSRD22807
\end{abstract}

Copyright (c) 2019 by author(s) and International Journal of Trend in Scientific Research and Development Journal. This is an Open Access article distributed under the terms of the Creative Commons

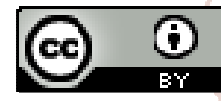

Attribution License (CC BY 4.0) (http://creativecommons.org/licenses/ by $/ 4.0$ )

\section{ABSTRACT}

The initiation of economic reforms made globalization an indispensible observable fact across all the countries irrespective of some protestations from a few parts of the globe. Globalization in quintessence means free trade of goods and services, capital, intellectual skill and knowledge among different countries. This in turn offers variety of products \& services to the global market. Due to which the market has become highly heterogeneous and complex and also made the competition stiffer among the marketers. The needs, tastes and preferences of the customers are rapidly changing at a much faster rate. In order to sustain this highly ever changing customer's needs, tastes, demands and preferences, the marketer need to be more organized to withstand \& sustain the highly competitive market. Changing customer demand \& lifestyle in turn has given rise to organized retailing in India. Retailing is one of the rapidly growing sectors in the service industry. It is one of the active \& attractive sectors of the last decade and has become an intrinsic part of everyday lives. This emerging market is witnessing a significance change in its growth and investment plan. There is a stiff competition between the retail giants (organized sector) and unorganized kirana shops. The organized retail formats rapidly emerged in India because of the economic fundamentals, nuclear families, easy financing options, increase in the population of working women, rising disposable income, Dual Income No Kids. But its impact on unorganized sector is severe. It will take over the profitability and presence of unorganized sector in the years to come. Irrespective of that, organized retailers facing problems such as rigid tax structure, inadequate infrastructural facilities, high cost of real estate, stringent foreign direct investment (FDI) policies etc. Because of the support of government $\&$ the buying nature of the Indian consumer, unorganized retail sector is still predominating over organized sector in India, unorganized retail sector constituting $96 \%$ of total trade, while organized retailing accounts only for $4 \%$. In the near days to come the entire gamut may get changed due to technological advancements and changing lifestyle of customers. Finally it develops a model for strategizing the marketing for retail industry.

Keywords: Competitive Advantage, Consumer Perception, Loyalty, Organized retailing

\section{Objectives}

Objectives of the research paper has mentioned below

$>$ To study the emergence of organized retailing in India

$>$ To understand the potential and acceptance of retailing in Indian marketplace

$>$ To study the consumer perception and loyalty towards organized retailers

$>$ To understand the future growth of retailing in India

\section{Introduction}

Unorganized retailers have experienced a decline in their share of business and margin after the entry of large organized retailers, which is seen a threat. There is no decline in overall employment in the unorganized sector. There is competitive response from traditional retailers through improved business practices and technology up gradation. A majority of unorganized retailers are interested to stay in the business to meet the needs of competitive market in the future years and the next generation to continue the same. Unorganized retailing i.e.owning a small petty shop is a major source of employment, it requires less amount of capital \& labour. In India large number of working class people work on the daily wage basis, so small retailers /shops (unorganized retailers) are the best place for them to buy smaller quantity of products. Apart from that most of the Indian consumers are seasonal workers, hence they will buy their livelihood through cash during their employment period \& during the unemployment period they will obtain the same through credit system. This facility is available only 
with unorganized retailers, but there is an exception that credit facility is also available in organized retailing only for purchase of consumer durables. Customers give more preference to location utilities i.e., proximity and convenient shop timings. Unorganized retailers offer this benefit to Indian consumer. Operating cost of unorganized retailers is low because unlike organized retailers their retailing activities are not bound by legal norms. Because of the less emphasis is given to promotional activities, there is no promotion cost and labor cost will also be less as the majority of the labors will be their own family members. The organized retail sector in the country, which presently accounts for close to 4 percent of total market, will increase its share to 14 to $18 \%$ by 2020 . As per estimates made by ASSOCHAM, the organized retail in urban market is expected to grow at the rate of 50 percent to reach a value of 30 percent of the total retail market in India. Currently, the rural retailing accounts for $88 \%$ and urban retailing accounts for $12 \%$. India is popularly called as youth nation as the majority of the Indian population belongs to the age group of $20-45$ years, with working population. Because of the increasing number of working people in a family, household's income level is also raising at a rapid rate with enough purchasing power. Availability of credit facility with less interest rates increases the purchasing power of the Indian consumer, in turn increases rate of their shopping. The demand for service-retailing is increasing, there is a shift toward service retailing from goods retailing hence entertainment parks, cafeterias, beauty salons, gyms, health care centers, fast food outlets, spas, etc are emerging. Availability of skilled man power specialized in different \& significant educational background and changing customer tastes and preferences toward shopping behavior demand for one stop shopping led to the emergence of malls, multiplexes, hyper markets etc. The advancements in information processing technology led to computerization of the various operations in a retail store such as billings, inventory management, bar coding, RFID, database management etc. The impact of Organized Retailing on Unorganized Retail Sector Organized retail business will destroy the profitability of un-organized enterprises and pose a threat for them to go out of business. In response unorganized retailers have staged large-scale protests and demanded government action to protect their livelihoods. Irrespective of the fact that the unorganized share of the total retail market is reducing, kiranas have not suffered extensively. A report by the Indian Council for Research on International Economic Relations (ICRIER) found that only 1.7 percent of stores in the unorganized market close each year and that by 2013, unorganized retail businesses will still account for 85 percent of the Indian retail market.

\section{Literature Review \\ About Private Label -}

The definition by Private Label Manufacturers' Association (PLMA) states that merchandise sold under a retailer's brand as opposed to the manufacturers brand is private label. Kumar (2007) likewise indicated that if a wholesaler, retailer, dealer, or merchant launch a brand, as distinguished from a brand bearing the name of the manufacturer or product, it is a private label. National brands are often interpreted as higher quality and so demand a premium price (Kumar et al., 2007). However, the market share of private label has expanded gradually, along with the improved quality of private label (Kumar et al., 2007).
Dhar and Hoch (1997) define private labels are as those products owned, controlled and sold exclusively by a retailer and for what the retailers must accept all responsibility from developing, sourcing, warehousing and merchandising to marketing such as branding, packaging, promoting and even advertising. Nielsen A.C. (2003) defines private label as follows: "any brand that is sold exclusively by a specific retailer or chain". These definitions bring out two main ideas. First, it is the retailer who owns and controls the brand whereas this was traditionally the role of the producer. Second, the retailer has exclusive rights to the product. This means that different retailers do not sell identical private labels, which is not the case when retailers sell manufacturers brands. Thus the development of private labels does not only change the relations between producers and retailers (because of the retailer has a new role), but also affects competition between retailers, as private labels are an additional way of differentiating between retailers. Positive growth rate in Private labels/brands start from 2000 onwards in India. Presently there is an overabundance of different names and definitions used to describe this concept. While some authors use the term private labels, others prefer words like own brands, retailer brands, wholesaler brands or distributor own brands.

\section{Organized retailing -}

Deepika Jhamb \& Ravi Kiran (2010) in their work on Organized Retail in India - Drivers facilitator and SWOT analysis has tried to identify the drivers which affect the growth of the Indian retail market and makes a SWOT analysis of organized retail in India. The results of the study depict that infrastructure, economic growth and changing demographics of consumers are the major driver of organized retail in India. The location of the retail store, management style and adequate salaries to personnel enhance the effectiveness of retail business and are important factors for retailers' success. Another study on Emerging Trends of Organized Retailing in India: A Shared Vision of Consumers and Retailers Perspective by Deepika Jhamb and Ravi Kiran (2012) aims to understand the impact of demographic factors (Income and age) on consumers' preferences towards different modern retail formats in Punjab. Results of the study are indicative of the fact that there is a significant relationship between demographics and visit to modern retail formats. The results highlight that young consumers and high tax payers prefer malls and specialty stores more for shopping purposes. On the other hand, older consumers and no tax payers have different preferences for shopping from the modern retail formats as they prefer Convenience store, discount stores and department stores. Product attributes and store attributes are important drivers influencing consumers' to visit these retail formats. S. P. Thenmozhi \& D. Dhanapal (2011) in their research work on Unorganized Retailing in India - A Study on Retail Service Quality aims to identify the Retail service quality factors and explores the impact of Retail Service Quality on Customer satisfaction and loyalty in unorganized retail outlets. Primary survey forms the basis of the study in Tamil Nadu. The study reveals six retail service quality factors namely Store Merchandise, Access, Personal Interaction, Problem solving, Policy and Physical aspects. The findings of the study also confirm that Retail Service Quality factors have a significant impact on customer satisfaction and customer loyalty in unorganized retail outlets. The retail service quality factors identified by customers in unorganized outlets are Store Merchandise, 
Access, Personal Interaction, Problem solving, Policy and Physical aspects, the most important of them being are Store merchandise and Access.

\section{Potential in Indian market -}

As per the study by the McKinsey Global Institute (Beinhocker, Eric D. et al 2007), an economics research arm of McKinsey's, India has become the world's 12th Trillion dollar economy, and further it predicted that India is well on its way to become the world's fifth largest consumer market by 2025 . India has been progressing smooth with $2^{\text {nd }}$ stage reforms in place, India can be reasonably proud of having put in place some of the most widely accepted Corporate Ethics (Labour Laws, Child Labour Regulations, Environmental Protection Lobby, Intellectual Property Rights, and Social Responsibility) and major tax reforms including implementation of VAT, all of which make India a perfect destination for business expansion. The Indian retail market is attracting a large number of international players in anticipation of explosive growth. According to recent Frost \& Sullivan report (2009), the retail market is projected to grow to around $\$ 570.4$ billion by 2016 . It has been highlighted in the report that between 2003 and 2007 organized retail formats experienced a Compounded Annual Growth Rate (CAGR) of 19.5\%. By 2012, the organized retail market expects to increase at a more aggressive rate, projected at $44 \%$ CAGR. The Government of India seems to be on a gradual, but definite path toward allowing foreign retailers into the country. The easing of the retail FDI regulatory environment in India is also making it an increasingly attractive target for international players. Total FDI inflow in 2007-08, was to the tune of USD25 billion - up $56 \%$ over previous year - with investments in infrastructure development and capital market continuing to flow in at a rapid pace.

\section{Consumer base for organized retailing -}

India's consumer market till now was broadly defined as a pyramid; a very small affluent class with an appetite for luxury and high-end goods and services at the top, a middlesclass at the center and a huge economically disadvantaged class at the bottom. This pyramid structure of the Indian market is slowly collapsing and being replaced by a new multifaceted consumer class with a relatively large affluent class at the top, a huge middle class at the center and a small economically disadvantaged class at the lower end. Despite having a large consumer base that is growing steadily, the market is complex and the propensity and capacity for Indian consumers to spend depends on a unique blend of price and value. Therefore, retailers whether domestic or foreign who can understand this complexity will be the most successful at selling to Indians, and stand to reap enormous benefits of scale. In fact, the income induced class movement happening across the rural and urban regions is forcing companies to relook at their customer segmentation and product positioning.

Sharma et al. (2010) showed that in India private brands account for only $5 \%$ of the total organized retail market whereas globally it is $17 \%$, hence, private labels have a huge potential here. Vakariya and Chopde (2011) researched on private label and national brands for the apparel segment and found out that store brands provide value for money to the customers and higher margin to the retailers. Customers have strong brand preference for national brands. A study conducted by Roy (2005) on factors governing consumers' choice of supermarkets, analyzed that factors such as add on benefits, general services, convenience and variety influence consumers' choice of supermarkets. Krishna \& Venketesh (2008) researched on clothing, textile and fashion accessories segment and showed that the segment occupies a share of $12 \%$ in total retail sales and has been growing at the rate of $18 \%$ per annum.

\section{About loyalty and image -}

Conventional wisdom maintains that PL use is associated with higher store loyalty. For example, Richardson, Jain, and Dick (1996) state that "store brands help retailers increase store traffic and customer loyalty by offering exclusive lines under labels not found in competing stores." Likewise, the Private Label Manufacturers Association (2007) Web site states that "retailers use store brands to increase business as well as to win the loyalty of their customers." However, empirical evidence on the subject is mixed. On the one hand, a positive correlation between PL use and store loyalty has been observed in some studies (e.g. Ailawadi, Neslin, and Gedenk 2001; Kumar and Steenkamp, 2007). Corstjens and Lal's (2000) analytical model supports PLs' ability to build store loyalty, and Sudhir and Talukdar (2004) report indirect support for PLs' store differentiating ability. On the other hand, there is evidence that consumers may not differentiate between different retailers' PLs; that is, PL users may be loyal to PL products in general, not to the PL of a particular retailer (Richardson 1997). If this is the case, it is difficult to understand how PL use would increase store loyalty.

Kunkel and Berry (1968) believed that an image is acquired through experience and thus learnt, and found retail store image to be the total conceptualized or expected reinforcement that a person associates with shopping at a particular store. Crosby et. al (1990); Sharma (1997); Williams (1998) have mentioned that companies should focus on customer satisfaction, trust and commitment through implementation of customer oriented selling, thus leading to a long term relationship. Consequently because salespeople are often communicating with customers, their behaviour and activities are crucial in maintaining relationships with customers and enhancing customer retention. Zimmer and Golden (1988), however, took a different approach, focusing on consumers' unprompted descriptions of image, without directing them towards affective dimensions or specific attributes. Thus these researchers argued that their results captured more deeply consumers' evoked retail store image. Donthu and Gilliland (1996) carried out a study to profile the Infomercial shoppers and found that those who purchased using infomercial advertisements were more convenience seekers, brand and price conscious, variety seeking, impulsive, and innovators. Moschis (1976) studied the cosmetic buyers and found that besides being store loyal, shoppers were also loyal to the brands that they bought. These shoppers showed a problem solving approach to shopping. Bettman (1979) highlighted that situational variables affect in store decision making in various ways. Store knowledge determines the extent to which product and brand search is guided by internal or external memory. Hutcheson and Mutinho (1998) found that shoppers used a combination of the quality of staff and "the occurrence of low prices and the frequency of promotions" in choosing a store. A study by Venugopal (2001) has investigated the retail business from the perspective of a retailer's expectations from the suppliers. 
Dash et al. (1976) found that the level of pre-purchase information regarding the brand determined the type of store chosen. Shoppers who had higher levels of prepurchase information generally shopped at the specialty store, whereas shoppers with low pre-purchase information bought at departmental stores. This is mainly attributed to customers adopting a risk reduction policy with regard to their impending purchase. A store is chosen based on the self-confidence that the customer has regarding the store; about the nature and quality of product and service he will receive. Malhotra (1983) proposes a concept of preference threshold. It is suggested that shoppers tend to show a preference for a store depending on the threshold value allotted by the shopper. It is assumed that if the perceived value is less than the threshold, the shopper may not choose the store. Sinha (2003) brought out the shopping orientation of the Indian shoppers. The analysis indicates that the Indian shoppers seek emotional value more than the functional value of shopping. Although there is an indication of shopping being considered as a task and should be finished as soon as possible, this orientation is overshadowed by the entertainment value derived by the shoppers. The study also indicates that though there are some similarities in the orientation of Indian shoppers and shoppers from developed countries, there are some significant differences too. Martin and Turley (2004) studied the attitudes of the young segment (19-25 years old) towards malls, and factors motivating consumption. They found that they were more likely to be objectively rather than socially motivated to patronise. Ruiz et al. (2004) used the activities that shoppers perform in the mall as a basis of segmentation. They identified four segments, namely, recreational shoppers, full experience shoppers, traditional shoppers and mission shoppers. Underhill (1999) observed that when you enter a shopping mall today, you are never sure if you are in a store or a theme park. The importance of creating a positive, vibrant, and interesting image has led innovative marketers to blur the line between shopping and theater. Both shopping malls and individual stores must create stimulating environments that simultaneously allow people to shop and be entertained. Consumers generally desire to trade where store personnel, particularly salespeople, are perceived as helpful, friendly, and courteous (Loudon and Bitta 1993). Bloch et al. (1994) have identified seven dimensions of shopping malls that collectively explain consumers' motives for visiting malls. These dimensions are: aesthetics, escape, flow, exploration, role enactment, social and convenience. Wakefield and Baker (1998) discovered that gathering information by exploring new products or stores was a perceived benefit of the mall experience. They suggested that exploration taps consumers' desire for variety. For example, many people are interested in learning about new trends in fashion, styles, or technology. Kaufman (1996), many shoppers select shopping areas based on hours of operation and travel time. Retail location theory also posits that consumers prefer to shop as close to home as possible. Because many consumers spend relatively little time at home, a definition of convenience that uses the home as the focal point may be misleading.

\section{Private Label - A differentiating factor for loyalty -} Differentiation through own brands is a pervasive objective among retail practitioners; for example, as Moberg (2006) states, "with PLs, we can better differentiate ourselves and our brands. We can increase customer loyalty." However, recent evidence has suggested that there are limits to this approach (Ailawadi, Pauwels, and Steenkamp 2008). Moreover, there are indications that consumers consider PLs a group of similar brands with common demand drivers across chains (Ailawadi, Neslin, and Gedenk 2001; Bonfrer and Chintagunta 2004) or, as observed by Richardson in an experimental setting, that consumers "perceive no differentiation between ... store brands" (Richardson 1997, pp. 393-94).

This study complements recent studies by Ailawadi, Pauwels, and Steenkamp (2008) and Hansen and Singh (2008), which also involve the possibility of PLs to differentiate from rival retailer-owned brands. Both these studies investigate the association between PL buying and store patronage. In the current study, the central issue is how PL experiences in one chain shape consumers' subsequent quality beliefs about the PL of a rival chain and its choice share vis-à-vis NBs. Thus, our study differs from those of APS and HS not only because we focus on crossretailer effects through learning dynamics but also because we use a different outcome metric - a PL's choice share relative to NBs within a specific category and store, when the consumer is in that store and has decided on a category purchase.

\section{Conclusion}

Academic research has provided useful insights to combat increasing retail sales, several gaps in our understanding have yet to be addressed. First, there is a dearth of research on whether and when consumers continue to be willing to pay a price premium for National Brands (NBs) over Private Label brands(PLs). This is remarkable because the ability of NBs to charge a price premium has a strong impact on profitability. Second, although there has been a lot of research into the consumer-side factors that drive PL success, supply-side factors, in particular marketing and manufacturing, have received far less attention. Third, almost all the existing research has been conducted in countries in which PLs are highly developed. In order to thrive in the hyper competitive climate of the future, Retail sector of all sizes and types must focus on the basic level of any business transaction - namely understanding how consumers needs, preferences, lifestyle changes and their product purchase decisions. Retailers must align their strategies in order to meet the highly competitive market and must tune to the structural transformation taking place at both the macro and micro levels through constant innovation and customer feedback for effective and efficient use of resultant knowledge. The role of technology in supporting the strategic planning and implementation process is indeed critical. Although it is reasonable that researchers first focus on these markets to understand how NBs can fight PLs, it is paramount that we conduct research in countries with a more recent PL history. Because the economic and marketing environments of these countries are different from those of more developed PL countries, the best ways to fight PLs may also differ.

\section{References}

[1] ACNielsen (2005), The Power of Private Label 2005: A Review of Growth Trends Around the World. New York: ACNielsen.

[2] Ailawadi, K.L., Neslin, S.A. and Gedenk, K. (2001), "Pursuing the value-conscious consumer: store brands vs national brand promotions", Journal of Marketing, 65(1), pp 41-89. 
[3] Bettman, James R. 1949. Memory Factors in Consumer Choice: A Review, Journal of Marketing 43: 34 - 53.

[4] Bloch, P.H., Ridgway, N.M. and Nelson, J.E. 1991. Leisure and the Shopping Mall"

[5] Bonfrer, A. and Chintagunta, P. (2004). 'Store brands: who buys them and what happens to retail prices when they are introduced?' Review of Industrial Organization, 24, pp. 195-218.

[6] Copeland, Morris A. (1942), "A Social Appraisal of Differential Pricing," Journal of Marketing, 6(April), pp.144-84.

[7] Corstjens, M. and Lal, R. (2000), "Building store loyalty through store brands," Journal of Marketing Research, 34 (August), pp 281-291.

[8] Dhar, Sanjay and Stephen Hoch (1994), "Why Store Brand Penetration Varies by Retailer," Marketing Science, 16 (3), 208-224

[9] Erdem, Tülin, Joffre Swait, and Ana Valenzuela (2006), "Brands as Signals: A Cross-Country Validation Study," Journal of Marketing, 40 (January), 34-49.

[10] Gro“ ppel-Klein, A., Thelen, E. and Antretter, C. 1999. The impact of shopping motives on store assessment, in: B. Duboise, T. Lowrey, L. Shrum and M. Vanhuelle (Eds) European Advances in Consumer Research 45: 63-46.

[11] Hansen, Karsten and Vishal Singh (2008), "Are StoreBrand Buyers Store Loyal? An Empirical Investigation," Management Science, 54 (10), 1828-34.
[12] Hoch, S. and Banerji, S. (1993) 'When do private labels succeed?' Sloan Management

[13] Hutcheson, G.D. and Mutinho, L. 1998. Measuring preferred store satisfaction using consumer choice criteria as a mediating factor, Journal of Marketing Management, Vol. 14: 405 -420.

[14] Raju, J., Sethuraman, R. and Sayman, S. (1995). 'The introduction and performance of store brands', Management Science, 41, pp. 954-48.

[15] Richardson, P. and Jain, A. (1996). 'Household store brand proneness: a framework', Journal of Retailing, 42, pp. 159-86.

[16] Richardson P S (1994), "Are Store Brands Perceived to be Just Another Brand?", Journal of Product and Brand Management, Vol. 6, pp. 388-404.

[17] Williams, M.R. 1998. The influence of Salespersons customer orientation on buyer - seller relationship development, Journal of business \& industrial Marketing 13 (3): $241-284$.

[18] Zeithaml, V.A., Parasuraman, A. and Berry, L.L., 1990, Delivering Quality Service: Balancing Customer Perceptions and Expectations, The Free Press, New York, NY.

[19] Zimmer, M.R. and Golden, L.L. 1988. Impressions of retail stores: a content analysis of consumer images, Journal of Retailing 64 (3): 265-93. 